\title{
The Closing of the Industrial Museum of the American Steel and Wire Company
}

It is with regret that the BuLLETIN notes the recent closing of the Industrial Museum of the American Steel and Wire Company at Worcester, Massachusetts. Founded in 1908 by William P. Palmer, then president of the Company, the Museum grew into a splendid collection of machinery, products, pictures, biographies, miscellaneous printed materials, and manuscripts dealing with the wire business from its earliest beginnings in the United States, especially with the history of the American Steel and Wire Company and its predecessors.

Besides preserving historical records which might otherwise have been destroyed, the Museum has performed other functions. Open to the public, it has been visited by many persons from Worcester and elsewhere, thus serving as a medium for instructing the public in the function, method, and product of industry. To the employees of the Company and to the Worcester community in general, the Museum has stood as a record of achievement in manufacture in which they could take a just pride. In these days of the de-personalizing or institutionalizing of industry, such a museum serves as something of a symbol of the close relationship between administration, ownership, and labor in coöperative effort.

The contents of the Museum have been divided between two depositories. The machinery and examples of products have been moved to the Natural History Museum in Worcester. Manuscripts, printed materials, and pictures have been presented to the Business Historical Society and moved to the Society's depository, Baker Library of the Graduate School of Business Administration, Harvard University. The acquisition of this collection by the Society was made possible through the efforts of its president, Mr. John W. Higgins, and the generosity of the American Steel and Wire Company.

A unique part of the collection is its pictures. These are made up of kodak pictures, etchings, drawings, photographs, etc. The subjects are buildings and grounds, machines, and men. The photographs of men-workers in groups and singly, top adminis- 
trators, department heads, salesmen, etc.-constitute a very interesting record of the kind of men who worked in the industry over a period of about a hundred years. This part of the collection may prove as valuable as it is unusual.

The manuscripts are largely original business records of the American Steel and Wire and its predecessors. There are account books and other manuscripts of the Crown Point Iron Company, an early concern in northern New York, and of the Schoenberger Iron Company, of Pittsburgh-the latter collection contains a volume of unusual interest, the company's credit rating book, 1863-75, of its customers throughout the country. The most valuable part of the manuscript collection is the records of the Washburn \& Moen Company, of Worcester. The original business papers of this company record the beginnings of Ichabod Washburn's wire manufacture in the 1830's and the development (under the leadership of Washburn until 1868 and of Philip L. Moen in 1868-91) of the world's largest maker of wire rods and wire and the largest unit in the formation of the American Steel and Wire Company in 1899. In this collection are the reminiscences about the business of a number of executives and employees who worked with Washburn \& Moen in the second half of the nineteenth century.

The materials in the American Steel and Wire Company collection offer an opportunity to study the history of a great subsidiary of the United States Steel Corporation, one that probably has the oldest strong roots. The complete and permanent classification of the collection will have to wait until the war is over.

\section{An Early Industrial Capitalist's Labor Policy and Management}

The current importance of labor administration in business highlights the need for a better understanding of the historical background of the relations of business and labor. No part of American history has been more inadequately handled. Three aspects of the history of labor have been emphasized above everything else: labor organization, the conflict of labor and employer, and "exploita- 